\title{
Diversity of culturable bacteria endowed with antifungal metabolites biosynthetic characteristics associated with tea rhizosphere soil of Assam, India
}

Jintu Dutta ${ }^{1,2}$ and Debajit Thakur ${ }^{*}$

\begin{abstract}
Background: Rhizosphere soil is a crucial niche for the diverse beneficial microbial communities in plant-microbe interactions. This study explores the antagonistic potential and diversity of the rhizosphere soil bacteria from commercial tea estates of Assam, India which comes under the Indo-Burma mega-biodiversity hotspot. Rhizosphere soil samples were collected from six different tea estates to isolate the bacteria. The bacterial isolates were subjected to evaluate for the antagonistic activity against fungal pathogens. The potential isolates were investigated for chitinase production and the presence of chitinase gene. The bacterial genetic diversity was studied by Amplified Ribosomal DNA Restriction Analysis (ARDRA) and BOX-PCR fingerprinting.

Results: A total of 217 rhizobacteria were isolated from tea rhizosphere soil, out of which 50 isolates exhibited the potential antagonistic activity against fungal pathogens. Among them, 12 isolates showed extracellular chitinase activity and the presence of chitinase genes. The chitinase genes were sequenced and the analysis of the sequences was performed by using PDB protein databank at the amino acid level. It showed the presence of ChiA and ChiA74 gene in the 6 most potent isolates which are involved in the hydrolysis of chitin. These isolates also exhibited antagonistic activity against all tested fungal pathogens. The diversity of 50 antagonistic bacterial isolates were analyzed through ARDRA and BOX-PCR fingerprinting. Diversity analysis and molecular identification of the rhizosphere isolates revealed that these antagonistic isolates predominantly belonged to the genus Bacillus followed by Enterobacter, Serratia, Lysinibacillus, Pseudomonas, and Burkholderia.
\end{abstract}

Conclusion: The present study establishes that rhizobacteria isolated from the poorly explored tea rhizosphere soil could be a rich reservoir for the investigation of potential antagonistic bacterial candidates for sustainable agricultural and industrial applications.

Keywords: Antagonist activity, ARDRA, BOX-PCR, Chitinase, Rhizosphere

\footnotetext{
* Correspondence: debajitthakur@iasst.gov.in

${ }^{1}$ Microbial Biotechnology Laboratory, Life Sciences Division, Institute of Advanced Study in Science and Technology, Guwahati, Assam, India

Full list of author information is available at the end of the article
}

(C) The Author(s). 2021 Open Access This article is licensed under a Creative Commons Attribution 4.0 International License, which permits use, sharing, adaptation, distribution and reproduction in any medium or format, as long as you give appropriate credit to the original author(s) and the source, provide a link to the Creative Commons licence, and indicate if changes were made. The images or other third party material in this article are included in the article's Creative Commons. licence, unless indicated otherwise in a credit line to the material. If material is not included in the article's Creative Commons licence and your intended use is not permitted by statutory regulation or exceeds the permitted use, you will need to obtain permission directly from the copyright holder. To view a copy of this licence, visit http://creativecommons.org/licenses/by/4.0/. The Creative Commons Public Domain Dedication waiver (http://creativecommons.org/publicdomain/zero/1.0/) applies to the data made available in this article, unless otherwise stated in a credit line to the data. 


\section{Background}

The factors controlling the distribution and abundance of soil microorganisms are still poorly understood despite soil microbes being the dominant engines of biogeochemical cycles and a major pool of living biomass in terrestrial ecosystems [14]. A recent study conducted using a variety of molecular or biochemical approaches has started to explore the distributional patterns exhibited by soil microbial communities and biotic or abiotic factors driving these patterns [30]. Among different soil types, rhizosphere soil is considered as one of the most active regions in soil that is governed by intense interactions between plant and root-associated microbes. The microbial communities residing in the rhizosphere play a pivotal role in plant growth promotion and protection. The rhizosphere soil bacteria thrive on root exudates efficiently and therefore the population of rhizosphere microbes is found to be higher than bulk soil [34]. Moreover, it was observed that the soil microbial and enzymatic properties respond relatively quickly to small changes that occurred in soil conditions and thus microbial properties and enzymes are considered to be good indicators of soil [40]. Among the different edaphic factors, the $\mathrm{pH}$ of the soil is also considered as a significant factor that affects the composition and diversity of soil bacterial communities [13, 17, 30, 37]. Moreover, the molecular studies on bacterial diversity have revealed a large richness of species, which promote plant growth and yield, compete for (or inhibit) pathogens, solubilize phosphate, or contribute to nitrogen assimilation in plants [29]. This technological advance has now become so pervasive that it is being regularly applied to explore soils and plants of agricultural interest.

The microbial interaction with tea plants is one of the less explored scientific area with potential future research. Tea plants are massively cultivated in Assam of Northeast India. The climatic condition and geographic location of the region are very much favorable for tea cultivation which makes entire India a leading tea production country in the world. However, this climatic condition of Northeast India offers a congenial environment for enormous numbers of fungal pathogens and pest invasion which leads to a considerable amount of crop loss annually. Tea plants are absolutely acclimatized to warm and humid conditions of the region, and the peculiar cultural conditions make them more disease susceptible [4]. The extensive use of pesticides, fungicides and other agrochemicals in order to control the diseases and pests, is also a burden to planters as well as to the environment that can also develop resistance or execute other economically important insects [16]. Therefore, one has to be very cautious and judicial about the use of such perilous chemicals in any crop fields. The demand for sustainable chemicals free production of tea also leading to a movement toward organic tea cultivation. Therefore, the present time demands the development in novel sustainable strategies for crop protection and enhancement that do not rely on harmful chemicals. Besides, the Northeast of India is also a part of the Indo-Burma mega-biodiversity hotspot [25] where microbial communities and their functions in soil of different regions are still to be explored.

The goal of the present study was to isolate the rhizosphere soil bacteria from different commercial tea estates located in Assam, India and evaluate them for the potential antagonistic activity against some major tea fungal pathogens. The antagonistic isolates were also screened for the presence of one of the major fungal cell wall degrading enzymes, the chitinase gene within their genome. Further, the analysis of antagonistic microbial diversity present in the tea rhizosphere soil was carried out by using Amplified Ribosomal DNA Restriction Analysis (ARDRA) and BOX-PCR fingerprinting. Therefore, this study was made an effort to investigate the promising rhizosphere soil bacteria for potential antagonistic activity against a wide array of major tea fungal pathogens.

\section{Results \\ Isolation of rhizobacteria}

A total of 217 rhizobacteria were isolated from rhizosphere soil in six different commercial tea estates of Assam, India. The culturable rhizobacteria were isolated from collected soil samples by using four different isolation media. The rhizobacterial isolates were enumerated based on their distinctive colonial morphology.

\section{In vitro antifungal assay}

All the 217 isolates were subjected for in vitro antifungal activity against six test phytopathogens to evaluate their antagonistic potential. From the assay, 50 (23\%) isolates exhibited positive antifungal activity. Out of these 50 positive isolates, $34(68 \%)$ isolates exhibited antagonistic activity against $N$. sphaerica (KJ767520), 33 (66\%) isolates showed antagonistic activity against $P$. theae (ITCC 6599), 19 (38\%) isolates showed antagonistic activity against C. eragrostidis (ITCC 6429), 27 (54\%) isolates showed antagonistic activity against G. cingulate (MTCC 2033), 24 (48\%) isolates showed antagonistic activity against $R$. solani (MTCC 4633), and 27 (54\%) isolates exhibited antagonistic activity against $F$. oxysporum (MTCC 284). Furthermore, 16 (32\%) isolates exhibited antifungal activity against at least four test pathogens and 6 (12\%) isolates i.e., HK28, SN18, SN25, HK17, TG1 and TT19 showed potential antagonistic activity which inhibited the growth of all six test fungal pathogens (Table 1, Fig. S1). 
Table 1 In vitro antifungal assay of rhizobacteria isolated from rhizosphere soil of different commercial tea estates of Assam, India against fungal phytopathogens

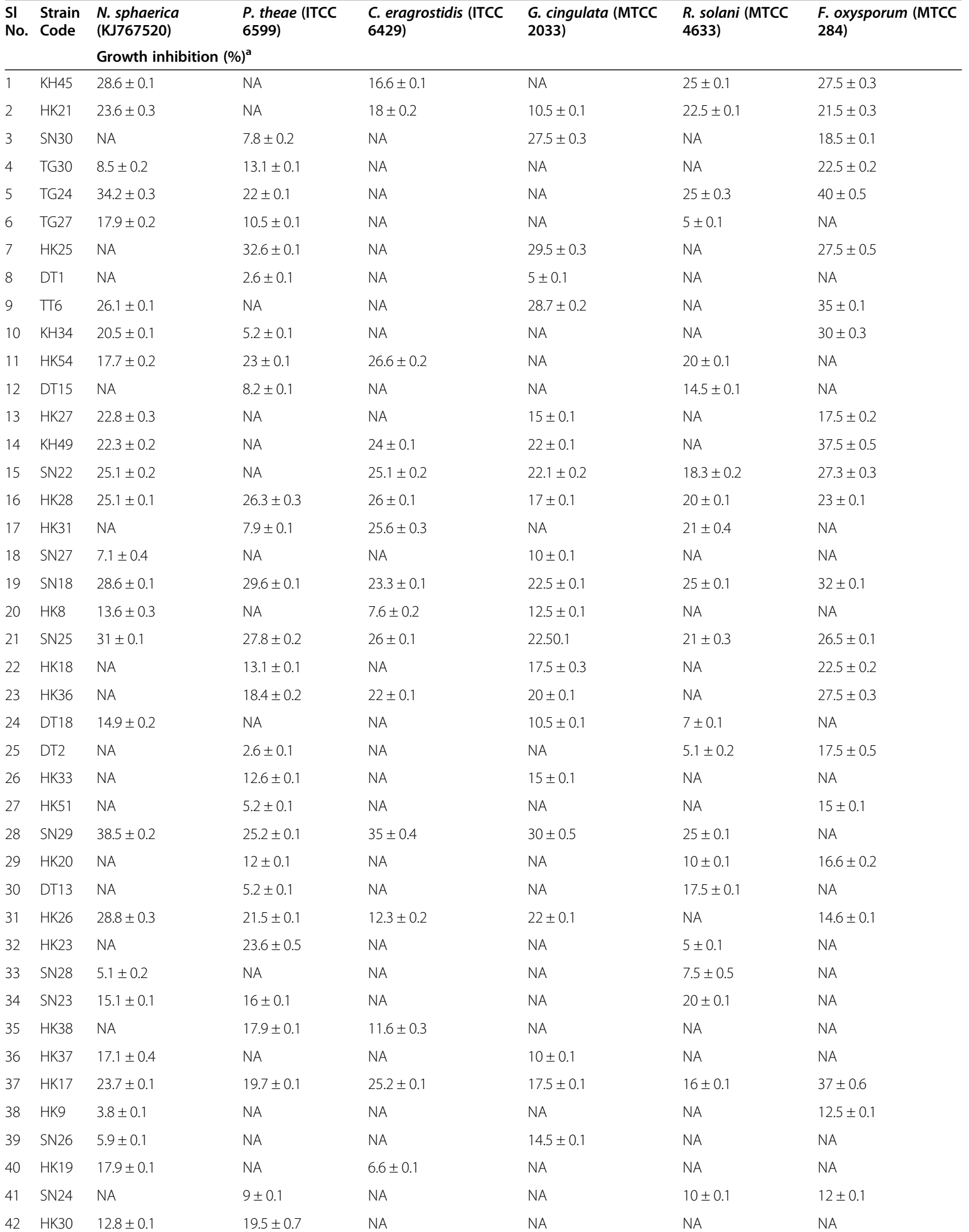


Table 1 In vitro antifungal assay of rhizobacteria isolated from rhizosphere soil of different commercial tea estates of Assam, India against fungal phytopathogens (Continued)

\begin{tabular}{llllllll}
\hline $\begin{array}{l}\text { SI } \\
\text { No. }\end{array}$ & $\begin{array}{l}\text { Strain } \\
\text { Code }\end{array}$ & $\begin{array}{l}\text { N. sphaerica } \\
\text { (KJ767520) } \\
\text { Growth inhibition (\%) }\end{array}$ & $\begin{array}{l}\text { P. theae (ITCC } \\
\text { 6599) }\end{array}$ & $\begin{array}{l}\text { C. eragrostidis (ITCC } \\
\text { 6429) }\end{array}$ & $\begin{array}{l}\text { G. cingulata (MTCC } \\
\text { 2033) }\end{array}$ & $\begin{array}{l}\text { R. solani (MTCC } \\
\text { 4633) }\end{array}$ & $\begin{array}{l}\text { F. oxysporum (MTCC } \\
\text { 284) }\end{array}$ \\
\hline 43 & DT9 & $3.5 \pm 0.2$ & NA & NA & $10.5 \pm 0.1$ & NA & NA \\
44 & HK32 & $31.6 \pm 0.5$ & NA & NA & $33.3 \pm 0.2$ & $14.6 \pm 0.1$ & $27.5 \pm 0.3$ \\
45 & HK2 & $23.1 \pm 0.2$ & $36.8 \pm 0.3$ & NA & NA & NA & NA \\
46 & KH18 & NA & $22.5 \pm 0.1$ & NA & $17.5 \pm 0.3$ & $N A$ & $15 \pm 0.1$ \\
47 & HK29 & $29.3 \pm 0.2$ & $12.1 \pm 0.2$ & NA & NA & NA & NA \\
48 & T119 & $30.3 \pm 0.2$ & $31.5 \pm 0.1$ & $18.5 \pm 0.3$ & $27.5 \pm 0.1$ & $25 \pm 0.1$ & $23.3 \pm 0.2$ \\
49 & TG1 & $42.6 \pm 0.2$ & $32 \pm 0.1$ & $32.5 \pm 0.3$ & $34 \pm 0.1$ & $28.5 \pm 0.1$ & $43.2 \pm 0.1$ \\
50 & DT23 & $5.1 \pm 0.1$ & NA & $4.3 \pm 0.1$ & NA & NA & NA
\end{tabular}

NA No Activity

${ }^{\mathrm{a}}$ Growth inhibition values are given as mean \pm SD $(n=3)$

\section{Chitinase production analysis}

The 50 antagonistic isolates were subjected to the extracellular chitinase production and out of which 12 (24\%) showed the most promising chitinase production. The chitinase producing isolates were further detected by PCR amplification of bacterial chitinase gene (Fig. S2). The sequencing of partial chitinase gene sequences was then translated to amino acid sequences for identification of their responsible chitinase gene and structures by using PDB protein databank. The amino acid sequences of the 8 isolates i.e., HK26, HK28, HK32, HK21, TG1, HK17, HK36 and KH49 showed 99\% similarity with the ChiA gene of the Serratia marcescens. This ChiA gene is important in the chitin hydrolysis [3]. The other 4 isolates SN18, TG24, SN25 and TT19 showed 100\% similarity at the amino acid level with ChiA74 gene of the Bacillus thuringiensis. The TIM-barrel/CID catalytic domain of ChiA74 of Bacillus thuringiensis involved in chitin hydrolysis [18] (Table 2).

\section{ARDRA and BOX-PCR fingerprinting analysis}

The restriction digestion profile of selected 50 potential antagonistic rhizobacteria was analyzed by ARDRA fingerprinting using three different restriction enzymes HaeIII, MspI, HinfI. The digestion with these endonuclease restriction enzymes showed different banding patterns and dendrogram was constructed by analyzing these banding patterns. The dendrogram was analyzed by using the DICE similarity coefficient which is divided into three board distinct clusters A, B and C (Fig. 1). The genus Bacillus was found as a dominant bacterial genus which is mostly grouped in cluster $C$, cluster B is composed of both the genus Serratia, and Enterobacter, and A is composed of genus Pseudomonas. Similarly, the BOX-PCR fingerprinting was carried out and the dendrogram was constructed by using the DICE similarity coefficient considering the band size between 500 bp to
$5 \mathrm{~kb}$ for scoring. The BOX-PCR generated a variation in the banding pattern of the isolates indicating the presence of different genotypes among the isolates (Fig. 2).

\section{Molecular identification and phylogenetic analysis}

The 16S rDNA of 36 representative isolates were selected and identified with their closest homolog match using EzBioCloud 16S database. The 16S rDNA molecular identification of the 36 representative isolates revealed that the genus Bacillus was the most dominant $(n=21,58.3 \%)$; followed by Enterobacter $(n=8,22.2 \%)$; Serratia $(n=3,8.3 \%) ;$ Lysinibacillus $(n=2,5.5 \%)$; Pseudomonas ( $n=1,2.7 \%)$; and Burkholderia $(n=1$, $2.7 \%$ ). The phylogenetic tree was constructed based on neighbour-joining (NJ) method (Fig. 3). Moreover, the representative ribotypes identified from the rhizosphere soil of Assam tea estates, their closest sequence similarity and origin were described in Table 3.

\section{Discussion}

There are diverse microbial communities that resides in the rhizosphere zone of plants and they are studied for their functional roles in the soil, plants and biogeochemical cycles. The aim of the present study was to study diverse autochthonous culturable antagonistic rhizobacterial communities present in the commercial tea estates of Assam, North-eastern part of India which is situated in the Indo-Burma mega-biodiversity hotspot. The presence of biodiversity hotspot in the region fuelled this study to search for the potential microbial isolates for the diverse biotechnological applications.

In this study, a total of 217 isolates were isolated from tea rhizosphere soil of six different commercial tea estates of Assam, India. The rhizosphere soil is a niche for diverse beneficial microorganisms and one of the most intensive plant microbe interactions zone. The $\mathrm{pH}$ of the soil range was found to be from 4.1 to 5.2 which 
Table 2 Amino acid sequence similarities of the chitinase gene of rhizobacteria with their activity and 3D structures in the PDB protein data bank

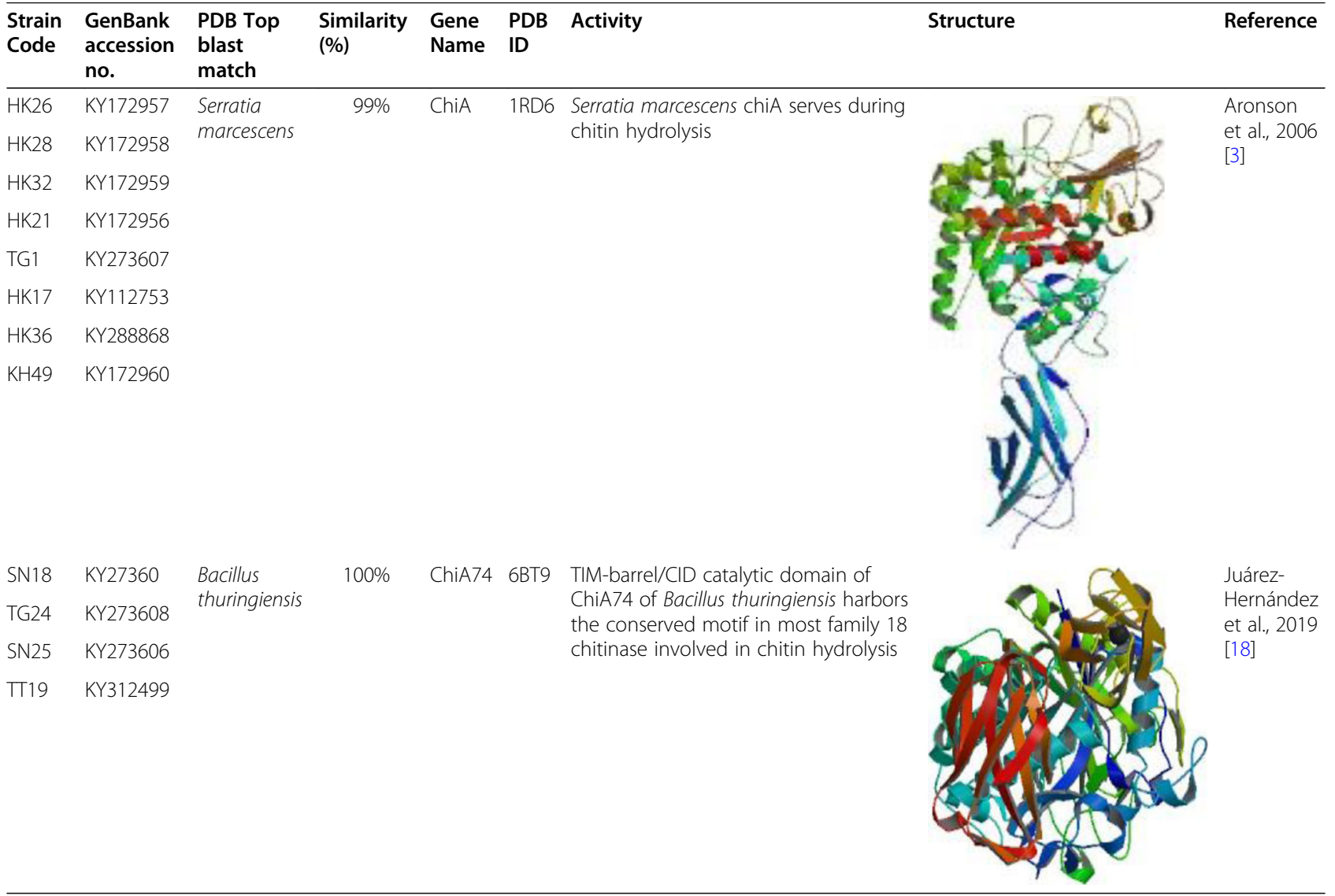

indicating to the soil is acidic in nature. Studies on tea plantations have shown that soil becomes low $\mathrm{pH}$ under tea plantation and also acidification determined the age and use of fertilizer in tea plantation [1,2].

The antagonistic activity of 217 isolates was carried out against six fungal phytopathogens and out of which 50 isolates showed potential antagonistic activity. These 50 isolates were considered as elite isolates for further investigation. Moreover, it was also observed that out of these 50 isolates, $16(32 \%)$ isolates exhibited antifungal activity against at least four test pathogens and $6(12 \%)$ isolates exhibited the antagonistic activity against all the test fungal pathogens. Plant associated rhizosphere microbial communities are considered as a crucial first line defence for disease suppression in plants. It was also observed that the root exudates of the infected plants are more attractive than uninfected plants to harbour the model strain Pseudomonas protegens CHA0 for production of disease suppressive antimicrobial metabolites [7]. The in vitro antifungal activity of Bacillus subtilis producing lipopeptides was tested against apple scab causing ascomycete fungi Venturia inaequalis [6]. Another study on gram-positive $B$. subtilis 30VD-1 has shown very potential antagonistic activity against ascomycete fungi
Fusarium sp. plant pathogen [19]. Similarly, gram negative Enterobacter sp. BNM 0357 strain isolated from rhizosphere soil has been demonstrated to inhibit up to $35 \%$ of the mycelial growth and spore germination of Fusarium solani [31]. In the present study, $2 \mathrm{~g}$ negative strains Enterobacter sp. HK28 and TG1 and 4 strains of gram-positive Bacillus sp. SN18, SN25, HK17 and TT19 have demonstrated board spectrum antifungal activity against five ascomycetes fungi i.e., $P$. theae (ITCC 6599), C. eragrostidis (ITCC 6429), G. cingulata (MTCC 2033), F. oxysporum (MTCC 284), N. sphaerica (KJ767520) and one basidiomycete fungal pathogen $R$. solani (MTCC 4633). This board spectrum antifungal result suggests that the rhizosphere soil of plant is a good source of potential antagonistic rhizobacteria to the encounter the plant pathogens.

Chitinases are very useful enzymes for different applications due to its key role in the degradation of crystalline polysaccharides. They catalyse the hydrolysis of $\beta-1$, 4-linkages in chitin which exert a direct inhibitory effect on the hyphal growth of fungal pathogens [27]. In our study, 12 isolates out of 50 potential antagonistic isolates showed the positive for extracellular chitinase activity in plate chitinase enzyme assay and PCR based chitinase 


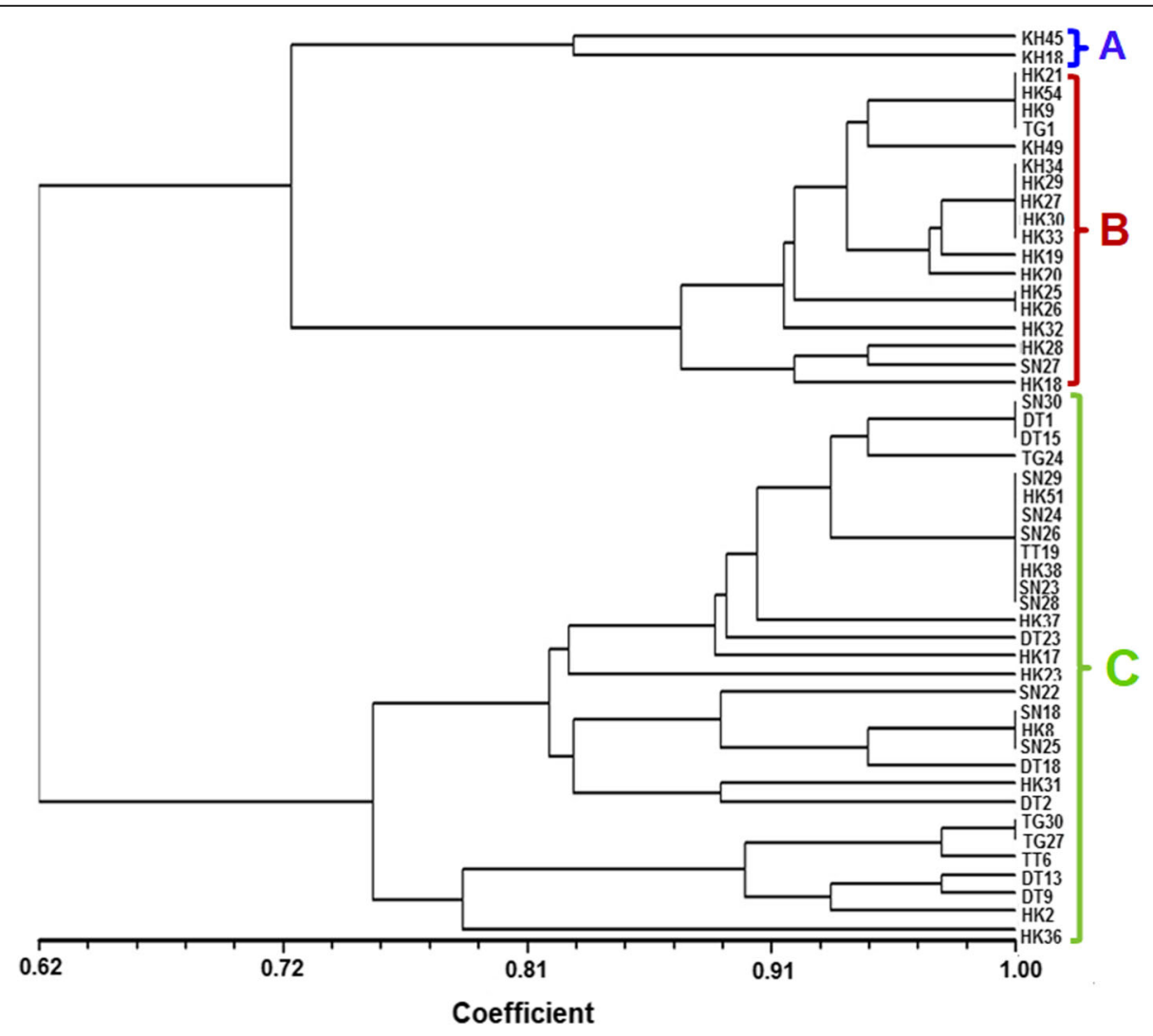

Fig. 1 UPGMA dendrogram generated by Dice similarity coefficient index from ARDRA banding patterns of 50 antagonistic rhizobacteria using NTSYS 2.02. The scale on the $x$-axis refers to the similarity coefficient

gene detection. Interestingly, the 6 isolates which showed board spectrum antagonistic activity against the fungal pathogens, also exhibited the chitinase activity and presence of chitinase gene. The analysis of the chitinase gene of 12 isolates at amino acid level with their $3 \mathrm{D}$ structures in PDB protein databank revealed that the isolates HK26, HK28, HK32, HK21, TG1, HK17, HK36 and KH49 showed 99\% similarity with the ChiA gene of the Serratia marcescens and isolates SN18, TG24, SN25 and TT19 showed $100 \%$ similarity at the amino acid level with ChiA74 gene of the Bacillus thuringiensis. A study on expression of different chitinase genes (ChiA, $\mathrm{ChiB}, \mathrm{ChiC}$ and $\mathrm{ChiD}$ ) was conducted at the transcriptional level and found that the presence of chitin strongly induced the ChiA gene for hydrolysis of chitin followed by others three chitinase genes [26]. Another study on combination of purified chitinases (ChiA, ChiB and ChiC) from $S$. marcescens strain CFFSUR-B2 isolate significantly suppressed the germination and germ tube growth of Mycosphaerella fijiensis causes black Sigatoka disease of banana [15]. The chitinase enzyme isolated from Serratia marcescens B4A strain exhibited strong antagonistic activity against Rhizoctonia solani, Bipolaris sp., Alternaria raphanin, and Alternaria brassicicola
[39]. Similarly, the Bacillus thuringiensis C25 isolate having cell wall degrading enzymes such as protease, $\beta-1,3-$ glucanase and chitinase were also reported to inhibit the mycelial growth, and suppression of sclerotia formation and germination of two major sclerotia phytopathogens [32]. The presence of chitinase gene in the 12 isolates of the present study strongly implies the exhibition of antifungal activity was due to the presence of chitinase enzyme. However, the absence of chitinase genes does not solely determine the antagonistic activity of the isolates because the other mechanisms or bioactive agents may be involved in the production of antifungal activity.

The ARDRA and BOX-PCR molecular genotyping are robust and most widely used for the classification and identification of culturable microbial communities at the level of genus and species [20]. These molecular tools are suitable and convenient for species-specific fingerprint and phylogenetic analysis [24]. The genetic diversity of the 50 antagonistic rhizobacteria through ARDRA using three different restriction enzymes HaeIII, MspI, HinfI and BOX-PCR fingerprinting revealed significant differences among the isolates. However, the bacterial diversity and richness in soil are largely differed by ecosystem type and $\mathrm{pH}$ of the soil or other edaphic variables 


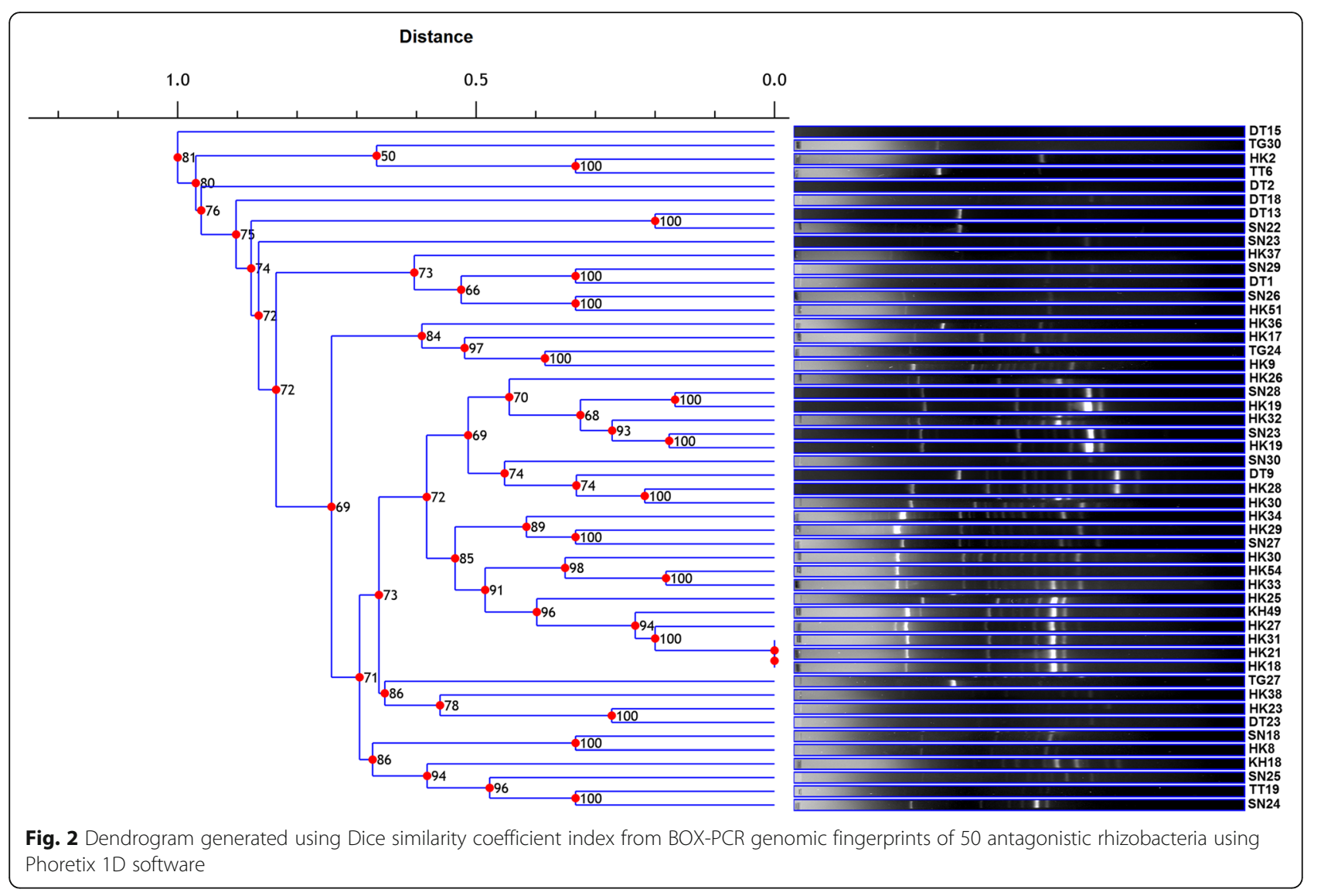

[13]. The study of microbial diversity and 16S rDNA sequencing of acidic soil of tea rhizosphere comprised of genus Bacillus, Enterobacter, Serratia, Lysinibacillus, Pseudomonas and Burkholderia. Based on the molecular fingerprinting and chitinase gene analysis, 36 representative ribotypes were selected for diversity analysis. The analysis of these ribotypes using EzBioCloud 16S database revealed that $21(58.3 \%)$ isolates belonged to the genus Bacillus, 8 (22.2\%) Enterobacter, 3 (8.3\%) Serratia, $2(5.5 \%)$ Lysinibacillus and 1 (2.7\%) isolate to each of the genus Pseudomonas and Burkholderia. The grampositive Bacillus and Bacillus like genus dominance was also reported by the previous studies on soil $[5,9,21$, 23]. From the present study, it was established that the genus Bacillus is also the most predominant group of bacteria in the tea rhizosphere soil of Assam, India.

\section{Conclusion}

The rhizosphere soil is a source of intensive microbial communities represents it beneficial effects on the overall health of the plant and soil. There is cross-talk between the plants and microbes in this zone to help each other in different adverse conditions. The diverse antagonistic bacterial communities present in the rhizosphere indicating its devoted service to the ecosystem management and protection of plants from various pathogenic microorganisms. Therefore, the findings in the present study revealed that antagonistic rhizobacteria isolated from the tea rhizosphere soil can be a valuable source for application in agriculture and industrial prospective.

\section{Methods}

Site description, sampling and isolation of bacteria

Assam state is located in the Northeast region of India and extending from $89^{\circ} 42^{\prime} \mathrm{E}$ to $96^{\circ} \mathrm{E}$ longitude and $24^{0} 8^{\prime} \mathrm{N}$ to $28^{0} 2^{\prime} \mathrm{N}$ latitude with an area of $78,438 \mathrm{~km}^{2}$. With the tropical monsoon rainforest climate, Assam is a temperate region and experiences heavy rainfall and humidity. The tea plantations are one of the most economically important plants grown in Assam. Because of its long growing season and generous rainfall, Assam is one of the most prolific tea-producing regions in the world. The state is cultivated in over 304,400 ha area with an annual production of 629.05 million $\mathrm{kg}$ which contributes more than $50 \%$ of the overall annual tea production of India.

The rhizosphere soil samples of tea plants were collected from 5 to $30 \mathrm{~cm}$ depth soil in sterile bags and transported immediately to the laboratory in icebox. 


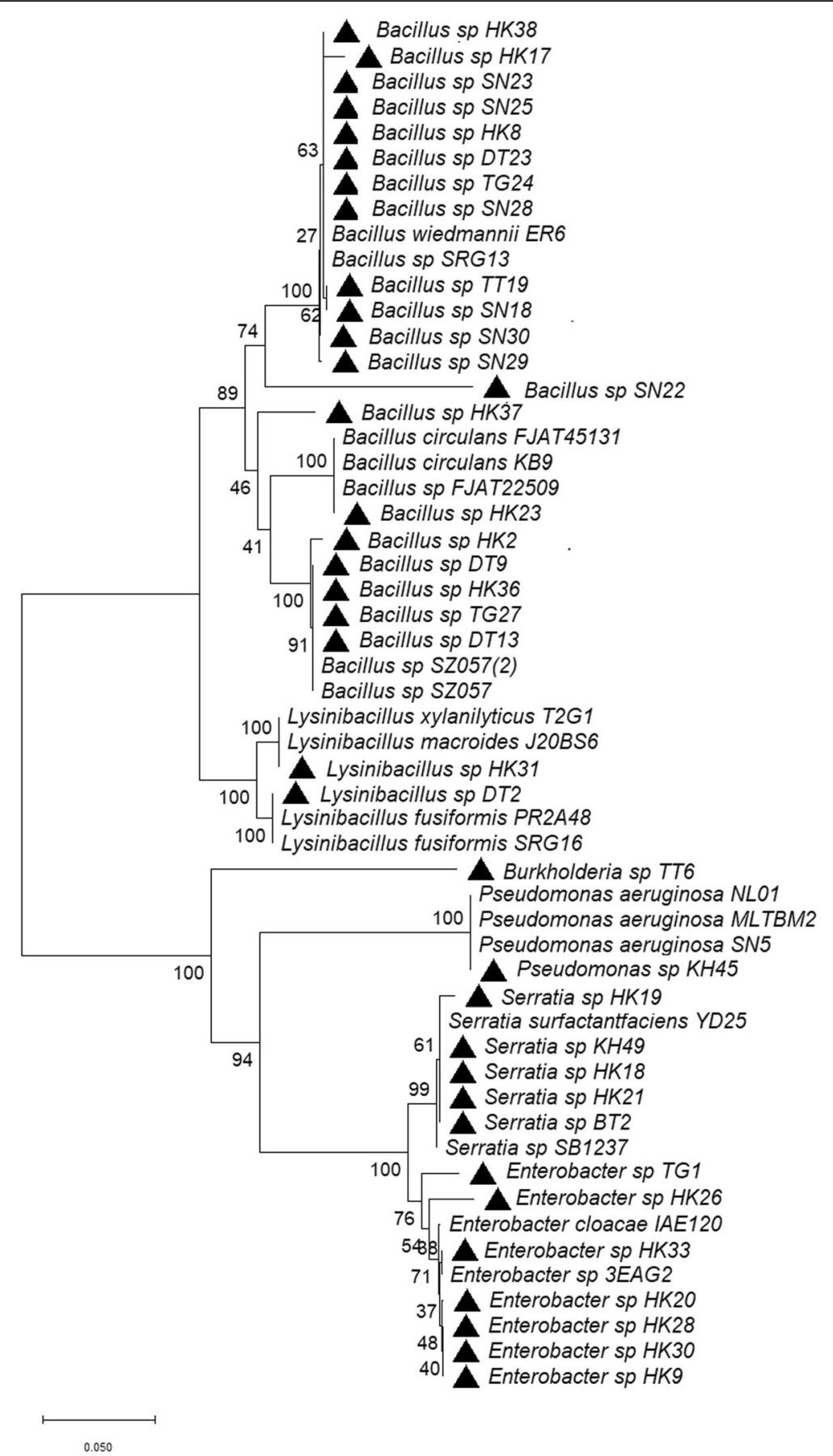

Fig. 3 Phylogenetic tree showing the evolutionary relationship between selected potential antagonistic rhizobacteria and closest type strains based on the $16 \mathrm{~S}$ rDNA sequences by NJ-method using Kimura-2 parameter model. The bar represents 0.05 substitutions per site, bootstrap values $(n=1000)$ are displayed

These soil samples were collected from six different tea estates located in Assam, India i.e. Sonapur tea estate $\left(26^{\circ} 06^{\prime} 56.40^{\prime \prime} \mathrm{N} 91^{0} 58^{\prime} 33.18^{\prime \prime} \mathrm{E}\right)$, Khetri tea estate $\left(26^{0} 06^{\prime} 53.81^{\prime \prime} \mathrm{N} 92^{\circ} 05^{\prime} 27.74^{\prime \prime} \mathrm{E}\right)$, Toklai tea growing area $\left(26^{\circ} 45^{\prime} 18.40^{\prime \prime} \mathrm{N} 94^{0} 13^{\prime} 16.92^{\prime \prime} \mathrm{E}\right)$, Difaloo tea estate $\left(26^{0} 36^{\prime} 29.41^{\prime \prime} \mathrm{N} 93^{0} 35^{\prime} 03.96^{\prime \prime} \mathrm{E}\right)$, Teok Tata tea estate $\left(26^{0} 36^{\prime} 29.41^{\prime \prime} \mathrm{N} 94^{0} 25^{\prime} 42.59^{\prime \prime} \mathrm{E}\right)$ and Hatikhuli tea estate $\left(26^{\circ} 34^{\prime} 55.94^{\prime \prime} \mathrm{N} 93^{\circ} 24^{\prime} 43.15^{\prime \prime} \mathrm{E}\right)$. These sampling sites was also previously described in our research article which was the part of our undergoing tea rhizosphere soil research work [8]. The bacteria were isolated from rhizosphere soil by using the serial dilution method. For 
Table 3 Molecular identification of 16S rRNA gene of representative antagonistic rhizobacteria with their sequence accession numbers and sample collection site from different commercial tea estates of Assam, India

\begin{tabular}{|c|c|c|c|c|c|c|}
\hline $\begin{array}{l}\text { Sl. } \\
\text { No. }\end{array}$ & $\begin{array}{l}\text { Isolate } \\
\text { Code }\end{array}$ & $\begin{array}{l}\text { GenBank } \\
\text { accession no. }\end{array}$ & $\begin{array}{l}\text { Base pair } \\
\text { length }\end{array}$ & $\begin{array}{l}\text { Top blast match with accession no. (EzBioCloud } \\
\text { 16S Database) }\end{array}$ & $\begin{array}{l}\text { Similarity } \\
(\%)\end{array}$ & Sampling site \\
\hline 1 & HK2 & KX986582 & 1417 & $\begin{array}{l}\text { Bacillus safensis FO-36b } \\
\text { ASJD01000027 }\end{array}$ & 100 & Hatikhuli tea estate \\
\hline 2 & HK8 & KX986583 & 1407 & $\begin{array}{l}\text { Bacillus mobilis 0711P9-1 } \\
\text { MACF01000036 }\end{array}$ & 100 & Hatikhuli tea estate \\
\hline 3 & HK9 & KX986584 & 1410 & $\begin{array}{l}\text { Enterobacter chuandaensis } 090028 \\
\text { MK049966 }\end{array}$ & 99.7 & Hatikhuli tea estate \\
\hline 4 & HK17 & KX986585 & 1350 & $\begin{array}{l}\text { Bacillus cereus ATCC } 14579 \\
\text { AE016877 }\end{array}$ & 98.7 & Hatikhuli tea estate \\
\hline 5 & HK18 & KX986586 & 1410 & $\begin{array}{l}\text { Serratia marcescens KRED } \\
\text { AB061685 }\end{array}$ & 99.8 & Hatikhuli tea estate \\
\hline 6 & HK19 & KX986597 & 747 & $\begin{array}{l}\text { Serratia marcescens SmUNAM836 } \\
\text { CP012685 }\end{array}$ & 98.9 & Hatikhuli tea estate \\
\hline 7 & HK2O & KX986598 & 763 & $\begin{array}{l}\text { Enterobacter sichuanensis WCHECI1597 } \\
\text { POVL01000141 }\end{array}$ & 99.5 & Hatikhuli tea estate \\
\hline 8 & HK21 & KX986587 & 1418 & $\begin{array}{l}\text { Serratia marcescens ATCC } 13880 \\
\text { JMPQ01000005 }\end{array}$ & 99.3 & Hatikhuli tea estate \\
\hline 9 & HK23 & KX986588 & 1410 & $\begin{array}{l}\text { Bacillus circulans ATCC } 4513 \\
\text { AY724690 }\end{array}$ & 99.7 & Hatikhuli tea estate \\
\hline 10 & HK26 & KX986599 & 649 & $\begin{array}{l}\text { Enterobacter cloacae LMG } 2683 \\
\text { Z96079 }\end{array}$ & 97.4 & Hatikhuli tea estate \\
\hline 11 & HK28 & KX986589 & 1405 & $\begin{array}{l}\text { Enterobacter chuandaensis } 090028 \\
\text { MK049966 }\end{array}$ & 99.9 & Hatikhuli tea estate \\
\hline 12 & HK30 & KX986600 & 763 & $\begin{array}{l}\text { Enterobacter ludwigiio EN-119 } \\
\text { JTL001000001 }\end{array}$ & 99.5 & Hatikhuli tea estate \\
\hline 13 & HK31 & KX986601 & 739 & $\begin{array}{l}\text { Lysinibacillus xylanilyticus DSM } 23493 \\
\text { LFXJ01000007 }\end{array}$ & 99.2 & Hatikhuli tea estate \\
\hline 14 & HK32 & KX986590 & 734 & $\begin{array}{l}\text { Enterobacter bugandensis EB-247 } \\
\text { FYBI01000003 }\end{array}$ & 99.5 & Hatikhuli tea estate \\
\hline 15 & HK33 & KX986602 & 816 & $\begin{array}{l}\text { Enterobacter sichuanensis WCHECI1597 } \\
\text { POVL01000141 }\end{array}$ & 99.8 & Hatikhuli tea estate \\
\hline 16 & HK36 & KX986603 & 751 & $\begin{array}{l}\text { Bacillus zhangzhouensis DW5-4 } \\
\text { JOTP01000061 }\end{array}$ & 99.1 & Hatikhuli tea estate \\
\hline 17 & HK37 & KX986604 & 881 & $\begin{array}{l}\text { Bacillus aryabhattai B8W22 } \\
\text { EF114313 }\end{array}$ & 100 & Hatikhuli tea estate \\
\hline 18 & HK38 & KX986605 & 813 & $\begin{array}{l}\text { Bacillus cereus ATCC } 14579 \\
\text { AE016877 }\end{array}$ & 99.5 & Hatikhuli tea estate \\
\hline 19 & DT2 & KX986595 & 777 & $\begin{array}{l}\text { Lysinibacillus fusiformis NBRC } 15717 \\
\text { AB271743 }\end{array}$ & 99.9 & Difaloo tea estate \\
\hline 20 & DT9 & KX986579 & 1413 & $\begin{array}{l}\text { Bacillus xiamenensis HYC-10 } \\
\text { AMSH01000114 }\end{array}$ & 99.9 & Difaloo tea estate \\
\hline 21 & DT13 & KX986580 & 1414 & $\begin{array}{l}\text { Bacillus pumilus ATCC } 7061 \\
\text { ABRX01000007 }\end{array}$ & 99.3 & Difaloo tea estate \\
\hline 22 & DT18 & KX986581 & 837 & $\begin{array}{l}\text { Bacillus toyonensis BCT-7112 } \\
\text { CP006863 }\end{array}$ & 91.5 & Difaloo tea estate \\
\hline 23 & DT23 & KX986596 & 811 & $\begin{array}{l}\text { Bacillus paramycoides NH24A2 } \\
\text { MAOI01000012 }\end{array}$ & 99.9 & Difaloo tea estate \\
\hline 24 & SN18 & KX986607 & 731 & $\begin{array}{l}\text { Bacillus proteolyticus } \\
\text { MACH01000033 }\end{array}$ & 99.9 & Sonapur tea estate \\
\hline 25 & SN22 & KX986591 & 1412 & $\begin{array}{l}\text { Bacillus marisflavi JCM } 11544 \\
\text { LGUE01000011 }\end{array}$ & 97.2 & Sonapur tea estate \\
\hline 26 & SN23 & KX986608 & 782 & $\begin{array}{l}\text { Bacillus nitratireducens } 4049 \\
\text { KJ812430 }\end{array}$ & 99.6 & Sonapur tea estate \\
\hline
\end{tabular}


Table 3 Molecular identification of 165 rRNA gene of representative antagonistic rhizobacteria with their sequence accession numbers and sample collection site from different commercial tea estates of Assam, India (Continued)

\begin{tabular}{|c|c|c|c|c|c|c|}
\hline $\begin{array}{l}\text { Sl. } \\
\text { No. }\end{array}$ & $\begin{array}{l}\text { Isolate } \\
\text { Code }\end{array}$ & $\begin{array}{l}\text { GenBank } \\
\text { accession no. }\end{array}$ & $\begin{array}{l}\text { Base pair } \\
\text { length }\end{array}$ & $\begin{array}{l}\text { Top blast match with accession no. (EzBioCloud } \\
\text { 16S Database) }\end{array}$ & $\begin{array}{l}\text { Similarity } \\
\text { (\%) }\end{array}$ & Sampling site \\
\hline 27 & SN25 & KX986609 & 794 & $\begin{array}{l}\text { Bacillus paranthracis Mn5 } \\
\text { MACE01000012 }\end{array}$ & 100 & Sonapur tea estate \\
\hline 28 & SN28 & KX986592 & 1402 & $\begin{array}{l}\text { Bacillus wiedmannii FSL W8-0169 } \\
\text { LOBC01000053 }\end{array}$ & 100 & Sonapur tea estate \\
\hline 29 & SN29 & KJ767523 & 1336 & $\begin{array}{l}\text { Bacillus pseudomycoides DSM } 12442 \\
\text { ACMX01000133 }\end{array}$ & 99.6 & Sonapur tea estate \\
\hline 30 & SN30 & KX986593 & 1392 & $\begin{array}{l}\text { Bacillus sp. AFS092012 } \\
\text { NVOR01000041 }\end{array}$ & 99.9 & Sonapur tea estate \\
\hline 31 & TG1 & KJ767522 & 1341 & $\begin{array}{l}\text { Enterobacter lignolyticus SCF1 } \\
\text { CP002272 }\end{array}$ & 99.6 & $\begin{array}{l}\text { Tocklai tea } \\
\text { growing area }\end{array}$ \\
\hline 32 & TG24 & KX986594 & 1410 & $\begin{array}{l}\text { Bacillus albus N35-10-2 } \\
\text { MAOE01000087 }\end{array}$ & 100 & $\begin{array}{l}\text { Tocklai tea } \\
\text { growing area }\end{array}$ \\
\hline 33 & TG27 & KX986610 & 823 & $\begin{array}{l}\text { Bacillus altitudinis } 41 \mathrm{KF} 2 \mathrm{~b} \\
\text { ASJC01000029 }\end{array}$ & 100 & $\begin{array}{l}\text { Tocklai tea } \\
\text { growing area }\end{array}$ \\
\hline 34 & TT6 & KJ767524 & 1315 & $\begin{array}{l}\text { Burkholderia ambifaria AMMD } \\
\text { CP000442 }\end{array}$ & 99.3 & Teok tea estate \\
\hline 35 & ПТ19 & KX986611 & 1415 & $\begin{array}{l}\text { Bacillus proteolyticus TD42 } \\
\text { MACH01000033 }\end{array}$ & 99.9 & Teok tea estate \\
\hline 36 & KH45 & KJ767521 & 1284 & $\begin{array}{l}\text { Pseudomonas aeruginosa JCM } 5962 \\
\text { BAMA01000316 }\end{array}$ & 99.7 & Khetri tea estate \\
\hline
\end{tabular}

this, $1 \mathrm{~g}$ of the soil was suspended in $9 \mathrm{ml}$ of saline solution (i.e., $0.9 \% \mathrm{NaCl}$ ) and kept in shaking condition for $30-45$ min at $200 \mathrm{rpm}$ and $30^{\circ} \mathrm{C}$. The soil suspension was then serially diluted up to $10^{-6}$ and $100 \mu \mathrm{l}$ from each dilution was evenly spread over the surface of four different isolation media agar plates i.e., Nutrient agar, Pseudomonas isolation agar, Azotobacter agar and Azospirillum agar (HiMedia, India). The plates were then incubated for $12-24 \mathrm{~h}$ at $30^{\circ} \mathrm{C}$ and bacterial colonies that appeared on different media were selected based on their different colony morphology [8].

\section{In vitro antifungal assay}

\section{Test fungal pathogens}

The six tea fungal pathogens were used for this study i.e., Pestalotiopsis theae (ITCC 6599), Curvularia eragrostidis (ITCC 6429), Glomerella cingulata (MTCC 2033), Rhizoctonia solani (MTCC 4633), Fusarium oxysporum (MTCC 284), and Nigrospora sphaerica (KJ767520). The fungal pathogens were obtained from the Microbial Type Culture Collection (MTCC), and the Institute of Microbial Technology, Chandigarh, India and Indian Type Culture Collection (ITCC), Indian Agricultural Research Institute, New Delhi, India. The Nigrospora sphaerica tea fungal pathogen was isolated, characterized and preserved at Institute of Advanced Study in Science \& Technology, Guwahati, India.

In vitro screening of tea rhizobacteria for antifungal activity The isolated rhizobacteria were subjected to evaluate their antagonistic potential against the selected tea fungal pathogens. The bacterial broth cultures were adjusted to $1 \times 10^{8} \mathrm{CFU} / \mathrm{ml}$ and a loopful of bacterial cultures was streaked equidistantly on the edge of the PDA plates. The $5 \mathrm{~mm}$ agar plug of the test fungal mycelium previously grown on the PDA plate was placed at the center of the test plate between the bacterial streaked lines. The plates were incubated at $28 \pm 2{ }^{\circ} \mathrm{C}$ for 5 days. The control plates were prepared with the fungal agar plug without the bacterial streaks. The antagonistic activity was evaluated by comparing the fungal mycelial diameter on control and test plates and the percentage of inhibition was calculated by using the formula $\mathrm{C}-\mathrm{T} /$ $C \times 100$, where, $C$ is the fungal mycelial diameter on the control plate and $\mathrm{T}$ is the fungal mycelial diameter on the test plate $[9,10]$. The experiments were performed in triplicates.

\section{Chitinase production Preparation of colloidal chitin}

For the preparation of colloidal chitin, $5 \mathrm{~g}$ of shrimp shells chitin (Sigma, USA) was slowly added into $100 \mathrm{ml}$ of cold $0.25 \mathrm{~N} \mathrm{HCl}$ with vigorous stirring and kept overnight at $4{ }^{\circ} \mathrm{C}$. The mixture was filtered through the filter paper into $200 \mathrm{ml}$ ice cold ethanol at $4{ }^{\circ} \mathrm{C}$ with rapid stirring. The chitin suspension was centrifuged at $10,000 \times \mathrm{g}$ for $20 \mathrm{~min}$ and the resultant chitin pellet was washed repeatedly with sterile distilled water until the $\mathrm{pH}$ became neutral [28]. The final concentration was adjusted to 10 $\mathrm{mg} / \mathrm{ml}$. 


\section{Chitinase production and PCR amplification of chitinase gene}

The bacterial isolates were evaluated for the hydrolysis of chitin by using spot inoculation method on MS media containing $1 \%$ chitin $(\mathrm{v} / \mathrm{v})$. After pouring the chitin containing medium into the petri plates, the bacterial inoculums were spotted on the plate and incubated for $48 \mathrm{~h}$ to observe the zone of clearance [12].

The genomic DNA was extracted by using QIAamp DNA mini kit (Qiagen, India), and the presence of bacterial chitinase gene were screened by using degenerate primes GA1F and GA1R [35]. The $10 \mu \mathrm{l}$ of PCR reaction volume comprised of $1 \mu \mathrm{l}$ of $10 \times$ Taq DNA buffer, 2.5 mM dNTP mix, $0.2 \mu \mathrm{M}$ of primers, $1 \mathrm{U}$ Taq polymerase and $1 \mu \mathrm{l}$ of $10 \mathrm{ng}$ concentration of template DNA. The amplifications were carried out in the proflex PCR system (Applied Biosystems, USA). The reaction was set as follows: an initial denaturation at $95^{\circ} \mathrm{C}$ for $5 \mathrm{~min}, 35 \mathrm{cy}$ cles of $1 \mathrm{~min}$ at $95^{\circ} \mathrm{C}, 30 \mathrm{~s}$ at $60^{\circ} \mathrm{C}, 1 \mathrm{~min}$ at $72{ }^{\circ} \mathrm{C}$ followed by one cycle of $7 \mathrm{~min}$ at $72{ }^{\circ} \mathrm{C}$ for the final extension. The partially amplified chitinase genes were sequenced and translated to amino acid sequences using the ORF-Finder (https://www.ncbi.nlm.nih.gov/ orffinder/). The resulting amino acid sequences were used as queries to search the related proteins in the PDB protein databank (PDB; http://www.rcsb.org/pdb/) using the BLAST algorithm based advanced sequence search with the default parameters.

\section{Amplified ribosomal DNA restriction analysis (ARDRA)}

The ARDRA technique is basically based on restriction endonuclease digestion of the amplified bacterial $16 \mathrm{~S}$ rDNA. The genomic DNA extraction, 16S rDNA PCR amplification and purification of the PCR product was carried out as previously described [9]. For ARDRA analysis, $20 \mu \mathrm{l}(50 \mathrm{ng})$ of $16 \mathrm{~S}$ rDNA purified PCR products were digested by $1.5 \mathrm{U}$ of three different restriction enzymes HaeIII, MspI, HinfI (New England Biolabs, UK) according to manufacturer's instruction and incubated for $3 \mathrm{~h}$ at $37^{\circ} \mathrm{C}$. The resulting digested fragments together with $100 \mathrm{bp}$ ladder (Merck Genei, India) were resolved by gel electrophoresis at $60 \mathrm{~V}$ on $2 \%$ agarose gels in $1 \times \mathrm{TAE}$ buffer containing $10 \mu \mathrm{g} / \mathrm{ml}$ of EtBr. The gel profile obtained were analyzed by considering, the character state " 1 " for clearly detected bands in the gel track and assigned " 0 " if it was absent or impossible to determine. The data matrix thus generated was calculated by Dice similarity coefficient. Each pairwise comparison was constructed from the similarity matrix by the unweighted pair group method with arithmetic mean (UPGMA) using DICE similarity coefficient and the TreePlot program in NTSYSpc 2.02e analysis package (Applied Biostatistics Inc., New York).

\section{BOX-PCR fingerprinting}

The fingerprinting of antagonistic bacterial isolates was performed by repetitive extragenic palindromic-PCR (rep$\mathrm{PCR})$. The rep-PCR was carried out by using the BOXA1R primer (5'-CTACGGCAAGGCGACGCTGACG-3') [24]. The PCR product obtained was subjected to electrophoresis with a 500 bp DNA ladder (Merck Genei, India) using $2 \%$ agarose gel in $1 \times$ TAE buffer containing $10 \mu \mathrm{g} /$ $\mathrm{ml}$ of $\mathrm{EtBr}$. The generated fingerprints were further analyzed by hierarchical clustering using DICE similarity coefficient in Phoretix 1D Pro gel analysis software (TotalLab Ltd., Newcastle upon Tyne, England).

\section{Molecular characterization and phylogenetic analysis}

For the 16S rDNA identification, the rhizobacteria were selected based on the chitinase activity, ARDRA and BOX-PCR fingerprinting using the facility at Scigenom Labs Pvt. Ltd. (Cochin, India). The raw forward and reverse sequences obtained after sequencing of the isolates were analyzed by Sequence Scanner 2.0 software (Applied Biosystems) to filter out the low-quality base calls. The low-quality base calls were trimmed from both the sequences and aligned to remove the overlap regions. Then the contigs generated were assembled and screened for chimeras using DECIPHER software [36]. The 16S rDNA sequences generated after screening were identified by EzBioCloud 16S database [38] and submitted to the GenBank. The 16S rDNA gene sequences of antagonistic bacterial isolates along with their closest homology sequences retrieved from NCBI GeneBank were aligned by using multiple sequence alignment CLUSTAL W algorithm executed in MEGA X software [33]. These aligned sequences were used to construct the phylogenetic tree using neighbour-joining (NJ) method by MEGA 6 program and evolutionary distances were computed with the help of Kimura's 2 parameter model [22]. Bootstrap analysis with 1000 replications using p-distance model was performed to estimate the confidence of a particular clade [11].

\section{Sequences submitted to GenBank database}

The 36 nucleotide sequences of $16 \mathrm{~S}$ rDNA of rhizobacterial isolates from Assam tea estates were submitted in GenBank under NCBI accession no. KJ767521-KJ767524 and KX986579-KX986611. The 12 chitinase gene sequences were submitted under GenBank accession no. KY17295660, KY273605-08, KY112753, KY288868, KY312499.

\section{Data analysis}

All experiments were performed in triplicates to calculate the mean values and data were expressed as mean \pm standard deviation. The isolates showing antagonistic activity against the different fungal pathogens were represented as Venn diagram using the multiple dataset analysis features of VENNTURE software. 


\section{Supplementary Information}

The online version contains supplementary material available at https:/doi. org/10.1186/s12866-021-02278-z.

Additional file 1 : Fig. S1. Venn diagram of antifungal assay showing distribution of 50 antagonistic rhizobacteria into six profiles which are representing the 6 test fungal pathogens. (*6 isolates showed antagonistic activity against all the test fungal pathogens). Fig. S2. PCR amplification of chitinase gene of 12 potential rhizobacteria. (M-100bp ladder, 1-12 chitinase positive rhizobacteria strains i.e., HK26, HK28, HK32, HK21, TG1, HK17, HK36, KH49, SN18, TG24, SN25 and TT19 respectively).

\section{Acknowledgements}

The authors would like to thank DBT, Govt of India for funding. The authors would like to thank Director, IASST, Guwahati, Assam, India, for providing necessary facilities for this work.

\section{Authors' contributions}

JD and DT designed the experiments. JD performed the laboratory experiments and data analysis. JD and DT wrote the manuscript and both the authors read and approved the final manuscript.

\section{Funding}

This work was supported by Department of Biotechnology (DBT), Govt. of India under RGYI scheme (Grant No. BT/PR6011/GBD/27/379/2012).

\section{Availability of data and materials}

The sequence analysis during the current study are available in the in GenBank repository under NCBI accession no. KJ767521-KJ767524, KX986579KX986611, KY172956-60, KY273605-08, KY112753, KY288868, KY312499.

\section{Declarations}

\section{Ethics approval and consent to participate}

Not applicable.

\section{Consent for publication}

Not applicable.

\section{Competing interests}

The authors declare that they have no competing interests.

\section{Author details}

${ }^{1}$ Microbial Biotechnology Laboratory, Life Sciences Division, Institute of Advanced Study in Science and Technology, Guwahati, Assam, India. ${ }^{2}$ Present Address: Centre for the Environment, Indian Institute of Technology, Guwahati, Assam, India.

Received: 30 November 2020 Accepted: 13 June 2021 Published online: 18 July 2021

\section{References}

1. Abe SS, Hashi I, Masunaga T, Yamamoto S, Honna T, Wakatsuki T. Soil profile alteration in a brown forest soil under high-input tea cultivation. Plant Product Sci. 2006;9(4):457-61. https://doi.org/10.1626/pps.9.457.

2. Alekseeva T, Alekseev A, Xu RK, Zhao AZ, Kalinin P. Effect of soil acidification induced by a tea plantation on chemical and mineralogical properties of Alfisols in eastern China. Environ Geochem Health. 2011;33(2):137-48. https://doi.org/10.1007/s10653-010-9327-5.

3. Aronson NN, Halloran BA, Alexeyev MF, Zhou XE, Wang Y, Meehan EJ, et al. Mutation of a conserved tryptophan in the chitin-binding cleft of Serratia marcescens chitinase A enhances transglycosylation. Biosci Biotechnol Biochem. 2006;70(1):243-51. https://doi.org/10.1271/bbb.70.243.

4. Baby UI. An overview of blister blight disease of tea and its control. J Plant Crops. 2002;30:1-12.

5. Beneduzi A, Ambrosini A, Passaglia LMP. Plant growth-promoting rhizobacteria (PGPR): their potential as antagonists and biocontrol agents. Genet Mol Biol. 2012;35(4 suppl 1):1044-51. https://doi.org/10.1590/S1415-4 7572012000600020 .
6. Desmyttere H, Deweer C, Muchembled J, Sahmer K, Jacquin J, Coutte F, et al. Antifungal activities of Bacillus subtilis lipopeptides to two Venturia inaequalis strains possessing different tebuconazole sensitivity. Front Microbiol. 2019;10:2327. https://doi.org/10.3389/fmicb.2019.02327.

7. Dudenhoffer JH, Scheu S, Jousset A. Systemic enrichment of antifungal traits in the rhizosphere microbiome after pathogen attack. J Ecol. 2016; 104(6):1566-75. https://doi.org/10.1111/1365-2745.12626.

8. Dutta J, Handique PJ, Thakur D. Assessment of culturable tea rhizobacteria isolated from tea estates of Assam, India for growth promotion in commercial tea cultivars. Front Microbiol. 2015;6:1252. https://doi.org/10.33 89/fmicb.2015.01252.

9. Dutta J, Thakur D. Evaluation of multifarious plant growth promoting traits, antagonistic potential and phylogenetic affiliation of rhizobacteria associated with commercial tea plants grown in Darjeeling, India. PLoS One. 2017;12(8):e0182302. https://doi.org/10.1371/journal.

10. El-Sayed WS, Akhkha A, El-Naggar MY, Elbadry M. In vitro antagonistic activity, plant growth promoting traits and phylogenetic affiliation of rhizobacteria associated with wild plants grown in arid soil. Front Microbiol. 2014:5:651. https://doi.org/10.3389/fmicb.2014.00651.

11. Felsenstein J. Confidence limits on phylogenies: an approach using the bootstrap. Evolution. 1985;39(4):783-91. https://doi.org/10.1111/j.1558-5646.1 985.tb00420.x

12. Ferrari AR, Gaber Y, Fraaije MW. A fast, sensitive and easy colorimetric assay for chitinase and cellulase activity detection. Biotechnol Biofuels. 2014;7(1): 37. https://doi.org/10.1186/1754-6834-7-37.

13. Fierer $\mathrm{N}$, Jackson RB. The diversity and biogeography of soil bacterial communities. PNAS. 2006;103(3):626-31. https://doi.org/10.1073/pnas. 0507535103.

14. Fierer N, Leff JW, Adams BJ, Nielsen UN, Bates ST, Lauber CL, et al. Crossbiome metagenomic analyses of soil microbes. PNAS. 2012;109(52):21390-5. https://doi.org/10.1073/pnas.1215210110.

15. Gutierrez-Roma MI, Holquin-Melendez F, Dunn MF, Guillen-Navarro K, Palacios GH. Antifungal activity of Serratia marcescens CFFSUR-B2 purified chitinolytic enzymes and prodigiosin against Mycosphaerella fijiensis, causal agent of black Sigatoka in banana (Musa spp.). BioControl. 2015;60(4):56572. https://doi.org/10.1007/s10526-015-9655-6.

16. Hazarika LK, Bhuyan M, Hazarika BN. Insect pests of tea and their management. Annu Rev Entomol. 2009;54(1):267-84. https://doi.org/10.114 6/annurev.ento.53.103106.093359.

17. Jenkins SN, Waite IS, Blackburn A, Husband R, Rushton SP, Manning DC, et al. Actinobacterial community dynamics in long term managed grasslands. Antonie Van Leeuwenhoek. 2009;95(4):319-34. https://doi.org/1 0.1007/s10482-009-9317-8

18. Juárez-Hernández EO, Casados-Vázquez LE, Brieba LG, Torres-Larios A, Jimenez-Sandoval P, Barboza-Corona JE. The crystal structure of the chitinase ChiA74 of Bacillus thuringiensis has a multidomain assembly. Sci Rep. 2019:9:2591.

19. Khan N, Martínez-Hidalgo P, Ice TA, Maymon M, Humm EA, Nejat N, et al. Antifungal activity of Bacillus species against Fusarium and analysis of the potential mechanisms used in biocontrol. Front Microbiol. 2018;9:2363. https://doi.org/10.3389/fmicb.2018.02363.

20. Khosravi H, Dolatabad HK. Identification and molecular characterization of Azotobacter chroococcum and Azotobacter salinestris using ARDRA, REP, ERIC, and BOX. Mol Biol Rep. 2019;47(1):307-16. https://doi.org/10.1007/s11033-01 9-05133-7.

21. Kim WI, Cho WK, Kim SN, Chu H, Ryu KY, Yun JC, et al. Genetic diversity of cultivable plant growth-promoting rhizobacteria in Korea. J Microbiol Biotechnol. 2011;21(8):777-90. https://doi.org/10.4014/jmb.1101.01031.

22. Kimura MA. Simple method for estimating evolutionary rates of base substitutions through comparative studies of nucleotide sequences. J Mol Evol. 1980;16(2):111-20. https://doi.org/10.1007/BF01731581.

23. Liu J, Cui X, Liu Z, Guo Z, Yu Z, Yao Q, et al. The diversity and geographic distribution of cultivable Bacillus-like bacteria across black soils of Northeast China. Front Microbiol. 2019;10:1424. https://doi.org/10.3389/fmicb.2019.01424.

24. Mishra RK, Pandey BK, Pathak N, Zeeshan M. BOX-PCR- and ERIC-PCR-based genotyping and phylogenetic correlation among Fusarium oxysporum isolates associated with wilt disease in Psidium guajava L. Biocatal Agri Biotechnol. 2015:4(1):25-32. https://doi.org/10.1016/j.bcab.2014.09.012.

25. Myers N, Russel MA, Cristina MG, Gustavo ABF, Jennifer K. Biodiversity hotspots for conservation priorities. Nature. 2000;403(6772):853-8. https:// doi.org/10.1038/35002501. 
26. Orikoshi H, Nakayama S, Miyamoto K, Hanato C, Yasuda M, Inamori Y, et al. Roles of four chitinases (ChiA, ChiB, ChiC, and ChiD) in the chitin degradation system of marine bacterium Alteromonas sp. strain 0-7. Appl Env Microbiol. 2005:71:811-1815.

27. Oyeleye A, Normi YM. Chitinase: diversity, limitations, and trends in engineering for suitable applications. Biosci Rep. 2018;38(4). https://doi.org/1 0.1042/BSR20180323.

28. Roberts WK, Selitrennikoff CP. Plant and bacterial chitinases differ in antifungal activity. J Gen Microbiol. 1988;134:169-76.

29. Rosenblueth M, Martínez-Romero E. Bacterial endophytes and their interactions with hosts. Mol Plant-Microbe Interact. 2006;19(8):827-37. https://doi.org/10.1094/MPMl-19-0827.

30. Rousk J, Bååth E, Brookes P, Lauber CL, Lozupone C, Caporaso GJ, et al. Soil bacterial and fungal communities across a pH gradient in an arable soil. ISME. 2010:4(10):1340-51. https://doi.org/10.1038/ismej.2010.58.

31. Shoebitz M, Ribaudo CM, Pardo MA, Cantore ML, Ciampi L, Cura JA. Plant growth promoting properties of a strain of Enterobacter ludwigii isolated from Lolium perenne rhizosphere. Soil Biology and Biochemistry. 2009;41: 1768-74.

32. Shrestha A, Sultana R, Chae JC, Kim K, Lee KJ. Bacillus thuringiensis C25 which is rich in cell wall degrading enzymes efficiently controls lettuce drop caused by Sclerotinia minor. Eur J Plant Pathol. 2015;142(3):577-89. https:// doi.org/10.1007/s10658-015-0636-5.

33. Tamura K, Stecher G, Kumar S. MEGA11: molecular evolutionary genetics analysis version 11. Mol Biol Evol. 2021;38(7):3022-7. https://doi.org/10.1093/ molbev/msab120.

34. Van Loon LC. Plant responses to plant growth-promoting rhizobacteria. Eur J Plant Pathol. 2007;119(3):243-54. https://doi.org/10.1007/s10658-007-91 65-1.

35. Williamson $\mathrm{N}$, Brian $\mathrm{P}$, Wellington EMH. Molecular detection of bacterial and streptomycete chitinases in the environment. Antonie Van Leeuwenhoek. 2000;78(3/4):315-21. https://doi.org/10.1023/A:1010225909148.

36. Wright ES, Yilmaz LS, Noguera DR. DECIPHER, a search-based approach to chimera identification for $16 \mathrm{~S}$ rRNA sequences. Appl Environ Microbiol. 2012;78(3):717-25. https://doi.org/10.1128/AEM.06516-11.

37. Wu Y, Zeng J, Zhu Q, Zhang Z, Lin X. pH is the primary determinant of the bacterial community structure in agricultural soils impacted by polycyclic aromatic hydrocarbon pollution. Sci Rep. 2017;7:40093.

38. Yoon SH, Ha SM, Kwon S, Lim J, Kim Y, Seo H, et al. Introducing EzBioCloud: a taxonomically united database of 165 rRNA gene sequences and wholegenome assemblies. Int J Syst Evol Microbiol. 2017;67(5):1613-7. https://doi. org/10.1099/ijsem.0.001755.

39. Zarei M, Aminzadeh S, Zolgharnein $H$, Safahieh A, Daliri M, Noghabi KA, et al. Characterization of a chitinase with antifungal activity from a native Serratia marcescens B4A. Braz J Microbiol. 2011;42(3):1017-29. https://doi. org/10.1590/S1517-83822011000300022.

40. Zhang C, Liu G, Xue S, Song Z. Rhizosphere soil microbial activity under different vegetation types on the loess plateau, China. Geoderma. 2011; 161(3-4):115-25. https://doi.org/10.1016/j.geoderma.2010.12.003.

\section{Publisher's Note}

Springer Nature remains neutral with regard to jurisdictional claims in published maps and institutional affiliations.

\section{Ready to submit your research? Choose BMC and benefit from}

- fast, convenient online submission

- thorough peer review by experienced researchers in your field

- rapid publication on acceptance

- support for research data, including large and complex data types

- gold Open Access which fosters wider collaboration and increased citations

- maximum visibility for your research: over $100 \mathrm{M}$ website views per year

At BMC, research is always in progress.

Learn more biomedcentral.com/submissions 